\title{
Misi Penyelamatan Diri: Dinamika Psikologis Rasa Malu Pasangan (Istri) Koruptor
}

\author{
Self-Rescue Mission: Psychological Dynamics of Shame in a \\ Corruptor's Wife
}

\author{
Wa Ode Saqya Hania ${ }^{1}$, Tina Afiatin ${ }^{2}$ \\ 1,2Fakultas Psikologi, Universitas Gadjah Mada
}

Submitted 1 April 2020 Accepted 10 July 2020 Published 28 May 2021

\begin{abstract}
Marriage is an interdependent relationship between husband and wife. When a husband commits a crime, such as corruption, it can cause shame for his partner. This study aimed to understand the psychological dynamics of shame in a corruptor's wife. The research participant was a wife who filed for divorce to her husband due to his involvement in a corruption case. The qualitative case study method was used in this study. Data was collected using in-depth interviews and documentation study. The results showed that the shame experienced by participants was manifested in the anger, disappointment, sadness, pain, loneliness, loss, fear of exposure, defect, and unhappiness. The shame experienced came from shared identity that threatening the participant's self-image. The coping methods displayed by the participant to get rid of the shame were: forgetting, breaking the shared identity by divorcing, and improving self-image. The dynamics of corruptor wife's shame involve three major factors, namely the characteristics of participant, the participant's expectation that her child has pride in their parents, and the participant's relationship with family.
\end{abstract}

Keywords: corruptor's wife; shame; wife's shame

Abstrak. Relasi perkawinan merupakan hubungan interdependensi antara suami dan istri. Ketika suami melakukan tindak pidana korupsi, maka dapat menimbulkan rasa malu bagi pasangannya. Penelitian ini bertujuan untuk memahami dinamika psikologis rasa malu pasangan (istri) koruptor serta faktor-faktor yang terlibat di dalamnya. Partisipan penelitian adalah seorang istri yang menggugat cerai suaminya akibat kasus korupsi yang dilakukan suaminya. Metode kualitatif studi kasus digunakan dalam penelitian ini. Pengambilan data dilakukan dengan wawancara mendalam dan studi dokumentasi. Hasil penelitian menunjukkan bahwa rasa malu yang dialami partisipan ter manifestasikan dalam perasaan-perasaan marah, kecewa, sedih, sakit, kesepian, kehilangan, takut terekspos, defect, dan tidak bahagia. Rasa malu yang dialami muncul dari adanya identitas bersama yang mengancam citra diri partisipan. Koping yang dilakukan partisipan untuk keluar dari rasa malu adalah dengan melupakan, memutus berbagi identitas dengan bercerai, dan memperbaiki citra diri. Dinamika rasa malu pasangan (istri) koruptor melibatkan tiga faktor yang berpengaruh besar, yakni karakteristik partisipan, keinginan partisipan agar anaknya memiliki kebanggaan atas orang tuanya, dan relasi dengan keluarga.

Kata kunci: koruptor; pasangan; rasa malu 
Korupsi merupakan tindakan melawan hukum dan perbuatan memperkaya diri sendiri atau orang lain, atau suatu korporasi yang dapat merugikan keuangan negara atau perekonomian negara (UU No. 31 Tahun 1999 tentang Pemberantasan Tindak Pidana Korupsi). Sebagai tindakan melawan hukum, perilaku korupsi termasuk tindakan kejahatan, bahkan sering disebut sebagai kejahatan luar biasa (extraordinary crime) karena dampak destruktif yang luar biasa pada berbagai aspek kehidupan. Pelaku tindakan korupsi (koruptor) akan dicap sebagai penjahat, dan apabila tindakan korupsinya terbongkar maka akan berdampak seseorang dapat kehilangan muka di depan publik akibat korupsi yang kemudian memunculkan emosi rasa malu (Tangney et al., 2014).

Dalam perilaku sosial, citra diri merupakan kunci untuk lebih memahami dinamika interpersonal individu karena sebagai makhluk sosial, manusia fokus pada citra dirinya di dalam publik (Zane \& Yeh, 2002). Setiap perilaku individu dalam konteks sosial dipengaruhi oleh perasaan malu yang timbul dari penilaian publik bahkan sekecil apa pun (Goffman, 1955). Oleh karena itu, pemantik terkuat dari rasa malu adalah social approbation (sorotan, pujian, pengakuan) dari lingkungan. Pelaku korupsi yang tertangkap mengaku merasa telah mempermalukan teman dan almamaternya, pelaku merasa dirinya terpuruk, harga dirinya runtuh, hubungan menjadi berantakan, anaknya sangat terpukul, malu, dan frustrasi (Mahfud, 2016). Kehidupan koruptor setelah putusan persidangan dinyatakan bersalah, begitu menderita. Selain itu, diberikannya hukuman pidana (kurungan) berdampak pada perasaan malu terlebih dengan adanya stigmatisasi yang diberikan oleh masyarakat.

Meskipun merasakan malu, sebaik-baik keluarga adalah tempat untuk kembali. Terutama bagi seorang pasangan (istri), tetap mendampingi adalah bentuk dukungan terhadap suami. Dalam kondisi ini, rasa malu yang dirasakan oleh istri direspons dalam bentuk approach behavior untuk memperbaiki pandangan diri di depan orang lain (de Hooge et al., 2010). Misalnya, Sefti istri dari Ahmad Fathanah yang merupakan terpidana kasus suap impor daging (Merdeka.com, 16 Mei 2013), Ratu Rita istri dari Akil Mochtar (RMOL.CO, 28 Mei 2014), atau Deisti Astriani Tagor istri dari tersangka Mega Korupsi eKTP Setya Novanto (Antarafoto.com, 25 Desember 2017). Dengan penampilan yang berbeda dengan kesehariannya, ketiga perempuan tersebut menggunakan penutup kepala (jilbab), dan ketiga perempuan tersebut tetap peduli dan setia mengunjungi para suami yang berada di rumah tahanan KPK. Perubahan penampilan keduanya mengindikasikan respons dari rasa malu yang dialami.

Menurut Olson et al. (2014) hubungan perkawinan merupakan relasi yang paling intim. Relasi perkawinan melibatkan intimasi emosi dan fisik yang sangat berpotensi memengaruhi perasaan bahagia atau puas. Relasi perkawinan merupakan relasi yang penting dan penuh tantangan. Pengalaman yang terjadi dalam relasi perkawinan dapat berpengaruh besar dalam kehidupan pasangan perkawinan tersebut dan juga pada kehidupan sosial secara luas. Pasangan memiliki keterikatan emosional pada setiap 
anggota yang membentuk hubungan interdependensi dalam keluarga (Olson et al., 2011). Apa yang terjadi pada salah satu pasangan akan memberi pengaruh besar para pasangannya. Hubungan interdependensi ini menyebabkan perubahan pada salah satu pasangan akan berpengaruh pula terhadap pasangannya (Goldenberg \& Goldenberg, 2013).

Rasa malu dapat dirasakan oleh pasangan dalam hubungan suami istri yang salah satunya melakukan pelanggaran hukum. Perilaku koruptor relevan dengan identitas sosial yang mereka alami bersama dengan pelaku korupsi yang menjadi refleksi negatif terhadap diri mereka sendiri (Welten et al., 2012; Lickel et al., 2005). Selain itu, adanya rasa empati juga menyebabkan pasangan membayangkan memosisikan dirinya dalam posisi individu yang melakukan perilaku yang memalukan (Welten et al., 2012). Malinen (2010) menyatakan bahwa merasa malu berarti merasa inferior, tidak berharga, terpapar (terekspos), merasa kurang, sakit, konyol, kesepian, tidak tampak, tidak dicintai, merasa ditolak, dan terasing.

Rasa malu dapat mendorong seseorang untuk melakukan perbaikan pandangan diri individu di depan orang lain (approach behavior to restore the self). Namun, ketika aksi ini tidak mungkin atau sangat berisiko untuk dilakukan, rasa malu akan mengaktivasi perilaku menghindar atau menarik diri untuk melindungi diri (avoidance or withdrawal behaviors to protect the self) (de Hooge et al., 2010). Motif pemulihan diri (approach behavior to restore the self) bergantung pada faktor situasional, sedangkan motif untuk melindungi diri individu dari bahaya lebih lanjut tidak dipengaruhi oleh faktor situasional. Sebagai konsekuensinya, perilaku pendekatan (approach behavior) yang dapat diaktivasi rasa malu dapat berubah seiring berjalannya waktu (de Hooge et al., 2011).

Lebih lanjut lagi, de Hooge et al. (2011) menjelaskan bahwa ketika seseorang merasa citra diri atau pandangan dirinya terancam atau bahkan rusak, hal yang pertama cenderung dilakukan orang tersebut adalah dengan memperbaiki citra dirinya atau mengembalikan pandangan diri yang positif akan dirinya. Sesuai dengan pernyataan Tracy, Robins, dan Tagney (2007), usaha untuk mengembalikan pandangan diri yang positif salah satunya dengan menghabiskan waktu untuk meraih penghargaan dan hubungan yang dapat meningkatkan rasa bangga.

Sebagai pusat emosi moral (Tangney et al., 2007), rasa malu dapat membantu individu untuk tetap "lurus dan dalam batasan" serta dianggap dapat menghambat semua perilaku atau sikap tidak baik, pelanggaran atau perbuatan salah, serta memotivasi perilaku reparatif - pengakuan, permintaan maaf (Tangney \& Dearing, 2002). Rasa malu tumbuh dari proses sosialisasi di dalam keluarga (Tangney \& Dearing, 2002). Dengan kata lain, keluarga juga memiliki peran preventif terhadap tindak pidana korupsi melalui penanaman rasa malu di dalam keluarga.

Rasa malu sebagai self-conscious emotion merupakan emosi yang penting dalam memotivasi dan meregulasi hampir seluruh pikiran, perasaan, dan perilaku individu 
(Tracy et al., 2007), termasuk dalam hal perilaku korupsi dan keluarga sebagai media sosialisasinya. Oleh karena itu, penelitian terhadap rasa malu pasangan yang suaminya terlibat kasus korupsi menjadi penting dilakukan dalam rangka memahami bagaimana dinamika psikologis rasa malu.

Tindakan preventif terhadap tindak pidana korupsi dapat menyelamatkan uang negara lebih banyak dibanding pemberantasan setelah korupsi terjadi (Tribunnews.com; 2014, Desember 10). Tentunya, hal ini juga dapat mengurangi dampak-dampak lainnya yang ditimbulkan akibat korupsi. Maka dari itu, sosialisasi rasa malu sangat penting untuk dilakukan karena bukan hanya mengubah relasi antar pasangan, namun pada akhirnya akan mengubah masyarakat secara keseluruhan (Altalib et al., 2013). Dengan demikian, penelitian mengenai rasa malu pada pasangan (istri) yang suaminya melakukan tindak pidana korupsi penting untuk dilakukan.

Keunikan penelitian ini adalah kriteria subjek penelitian dengan status pernikahan bercerai sebagai akibat kasus korupsi pasangan. Berdasarkan penelusuran peneliti di lapangan, Yogyakarta sebagai kota di mana kasus korupsi cenderung rendah $(\mathrm{IPK}=5,81)$ dibandingkan 50 kota lainnya di Indonesia (Transparency International Indonesia, 2010), per 28 April 2018 kasus perceraian akibat korupsi hanya ada 1 di antara 49 Warga Binaan Pemasyarakatan (WBP) tindak pidana korupsi yang ada di Lapas Kelas IIA Yogyakarta. Artinya, perbandingan antara pasangan bercerai dan pasangan tidak bercerai pada WBP tindak pidana korupsi adalah 1:48. Sesuai dengan latar belakang, dari 49 narapidana kasus korupsi di lapas Yogyakarta, hanya ada satu narapidana yang status pernikahannya bercerai dan perceraian terjadi ketika narapidana (suami yang melakukan tindak pidana korupsi) berada di penjara. Oleh karena itu, perceraian pada narapidana kasus korupsi merupakan kejadian yang langka dan unik di Yogyakarta. Fokus pertanyaan penelitian adalah a) Bagaimana dinamika psikologis rasa malu seorang istri yang bercerai karena suaminya melakukan tindak pidana korupsi? b) Bagaimana relasi istri yang suaminya melakukan tindak pidana korupsi?

\section{Metode}

Pendekatan single case subject digunakan dalam penelitian ini berdasarkan kelangkaan subjek dan kasusnya. Studi kasus adalah metode dalam pendekatan kualitatif dengan jumlah partisipan yang sedikit (small-N), berada dalam seting nyata, dan digunakan untuk membedah fenomena secara lebih intensif (Gerring, 2007). Semakin sedikit kasus maka semakin intensif kesempatan peneliti untuk menjelaskan bagaimana dinamika pengamatannya terhadap sebuah kasus yang unik dari waktu ke waktu. Oleh karena itu, single case single subject menjadi memungkinkan untuk menyediakan hasil yang kredibel dalam desain ini, karena peneliti melakukan wawancara beberapa kali (lihat dokumen pelengkap) dan melakukan triangulasi untuk menggali fenomena. Tujuan dari penelitian 
ini adalah melihat gambaran dinamika psikologis rasa malu seorang istri yang bercerai ketika suami divonis tindak pidana korupsi.

\section{Partisipan}

Partisipan penelitian ini adalah satu orang perempuan yang bercerai karena pasangan melakukan tindak pidana korupsi. Partisipan bercerai ketika pasangan divonis melakukan tindak pidana korupsi. Kriteria partisipan penelitian (purposive sampling), yaitu seorang perempuan (istri) yang bercerai setelah pasangannya terbukti melakukan tindak pidana korupsi (tipikor) dan bersedia untuk diwawancara oleh peneliti. Selain itu, kasus tipikor pasangan juga telah selesai dan divonis bersalah oleh pengadilan.

Peneliti mendatangi Lapas (Lembaga Pemasyarakatan) untuk menemui Warga Binaan Pemasyarakatan (WBP) dengan kasus tipikor kemudian meminta izin dan kesediaannya untuk peneliti menghubungi istrinya. Kemudian peneliti bertemu dengan empat WBP tipikor. Pada awalnya, dari empat WBP ditemui, tiga WBP mengizinkan peneliti untuk menghubungi dan bertemu anggota keluarganya, sedangkan yang satu WBP tidak mengizinkan. Seiring dengan pertemuan building rapport antara peneliti dan calon partisipan, tiga istri WBP tidak bersedia melanjutkan partisipasi dalam penelitian. Istri WBP 1 sedang melanjutkan sekolah di luar negeri, istri WBP 2 menyatakan bersedia, namun terus menghindar ketika diminta untuk wawancara, istri WBP 3 dan 4 menyatakan bersedia, namun langsung mengundurkan diri ketika peneliti sedang melakukan building rapport.

Dari keempat anggota WBP tersebut, hanya WBP 1 yang status pernikahannya bercerai (memenuhi kriteria), dan lebih kooperatif untuk bergabung dalam proses wawancara. Peneliti kemudian menemukan kontak istri WBP 1 setelah satu minggu mengamati dan mencari akun media sosialnya. Setelah menemukan, peneliti mencoba mengkonfirmasi kebenaran hubungan antara nama yang peneliti temukan dengan orang pertama di lapas dengan cara menelusuri artikel-artikel yang berhubungan sampai akhirnya peneliti bisa mengkonfirmasi bahwa nama dan media sosial yang peneliti temukan benar milik istri dari WBP 1. Setelah menemukan calon partisipan, peneliti menghubungi via Direct Message Instagram partisipan dan menanyakan kesediaannya. Calon partisipan mengajukan beberapa pertanyaan yang kemudian peneliti jawab dan akhirnya calon partisipan bersedia untuk menjadi partisipan penelitian.

\section{Pengumpulan dan pengujian keabsahan data}

Sumber data yang digunakan dalam penelitian ini adalah partisipan penelitian, informan crosscheck (significant others/pasangan dan teman dekat), serta dokumen (postingan media sosial Instagram, chat Whatsapp, Blog, putusan pengadilan, dan artikel surat kabar online). Pengumpulan data dilakukan melalui wawancara mendalam dan studi dokumentasi. Pengujian keabsahan data dilakukan dengan berbagai macam cara. 
Studi kasus memiliki ciri umum menekankan pada proses pengumpulan data yang multi sumber (Kahija, 2017). Penelitian ini menggunakan triangulasi sebagai teknik pengujian keabsahan datanya. Adapun beberapa langkah yang dilakukan adalah mengecek dan membandingkan data yang diperoleh dari partisipan penelitian kepada pihak yang terkait, maupun pihak yang mengenal dan mengetahui partisipan dengan baik, yaitu pasangan dan teman dekat partisipan. Selain itu, peneliti juga membandingkan data hasil wawancara dengan data hasil studi dokumentasi, baik dari chat Whatsapp, Instagram, Blog, maupun artikel surat kabar online.

\section{Prosedur analisis data dan interpretasi}

Langkah-langkah yang dilakukan peneliti dalam proses menganalisis data penelitian adalah data dari hasil wawancara dan studi dokumentasi diubah menjadi transkrip yang keduanya kemudian dimuat di Microsoft Word untuk dilakukan tahap berikutnya. Setelah itu, peneliti membaca kembali secara keseluruhan data yang telah dikumpulkan dan diolah. Kemudian, dari setiap data yang ada, peneliti mengidentifikasi unit-unit data yang menjadi perhatian melalui fitur comment yang ada di Microsoft Word . Setelah itu, unit-unit data yang menjadi perhatian diurutkan dan dibuat ke dalam prototema. Pada proses ini, selain melakukan inductive thematic analysis, peneliti juga mengacu pada teknik theory-led thematic analysis. Setelah terbentuk prototema, peneliti kembali membaca transkrip dan memeriksa semua konten telah relevan dengan tema-tema tertentu. Setelah mendapatkan tema-tema final, peneliti memilih ilustrasi data untuk melaporkan tema.

\section{Hasil}

\section{Karakter pribadi partisipan}

KK merupakan seorang perempuan suku Jawa yang berusia 32 tahun, seorang PNS (akademisi), dan sedang melanjutkan sekolah S3 di luar negeri dengan bantuan beasiswa. KK kuliah sambil bekerja di negeri orang. KK memeluk agama Islam. KK adalah anak terakhir dari 2 bersaudara dengan kakak seorang laki-laki. Dalam berelasi dengan orang lain, KK ingin orang lain mengerti dirinya dan selalu ada untuknya. Sifat kritisnya dalam melihat sesuatu dan mempertanyakan sesuatu yang tidak terfasilitasi membuat KK lebih banyak mencari penyelesaian di luar keluarga. Bagi KK, adalah hal penting untuk bisa menyalurkan pikiran dan perasaannya. Jika orang lain tidak bisa memahaminya, maka sulit bagi KK untuk berelasi dengan orang tersebut. Menyadari bahwa dirinya memiliki karakter demikian, maka prinsip utama KK dalam berelasi adalah komunikasi. KK harus merasa nyaman dengan orang lain ketika berkomunikasi. Jika ia tidak merasa nyaman, sulit bagi KK untuk mempertahankan relasinya.

\section{Keadaan rumah tangga ketika pasangan menerima jabatan di pekerjaan}


Selama berumah tangga dengan pasangan, KK dan pasangan memiliki prinsip egaliter. Pengambilan keputusan di dalam rumah tangga diambil bersama, termasuk siapa yang bekerja, kapan memiliki anak, dan urusan seperti menggunakan pembantu atau tidak di rumah. KK dan pasangan sering berbagi cerita baik mengenai pekerjaan maupun mengenai perkembangan anak.

Saat menyampaikan bahwa pasangan ditawari menjabat sebagai Pejabat Pembuat Komitmen (PPK). Pada saat itu, pasangan merupakan orang baru di lembaga tersebut dan PPK termuda di kantornya. Karakteristik pasangan yang risktaker, didukung dengan izin dari KK membuat pasangan menerima jabatan tersebut. Ibu KK memperingatkan bahwa jabatan tersebut adalah jabatan yang rawan. Pada saat itu, KK tidak terlalu memikirkan nasihat ibunya akan hal itu, sehingga mengizinkan saja pasangannya untuk menerima jabatan itu. Sifat KK cenderung mementingkan hal-hal pragmatis, sehingga selama pasangan tetap bisa bersamanya KK akan membiarkan pasangan melakukan apa pun.

\section{Keadaan hubungan suami-istri sebelum dan sesudah kasus}

Sebelum ada kasus yang menimpa pasangan, KK merasa bahwa keluarganya adalah mimpi yang menjadi kenyataan. Memiliki anak dan memiliki pasangan adalah impiannya yang terwujud. KK merasakan kebahagiaan dalam pernikahannya. Keluarga KK juga saling menyayangi satu sama lain.

“.. jadi saya menikah dengan pak BP, punya anak kita punya rumah, it's kind like dreams come true gitu loh..."(KK79)

Setelah ada kasus, KK merasa mimpi yang indah berubah menjadi sebuah tragedi yang besar. Kasus yang menimpa keluarganya dianggap sebagai pemecah belah keluarganya dan awal dari kegagalan rumah tangganya.

“..jadi kan ya, it's kind like tragedy gitu loh. Ngga hanya disaster tapi beneran tragedi, jadi bener bener memecah belah semuanya dan kayak beneran turning point semuanya gitu." (KK103)

Persepsi, perasaan, sikap, dan respons perilaku ketika menghadapi kasus korupsi yang dilakukan oleh pasangan

Ketika pertama KK mendengar ada masalah yang menimpa pasangan, KK langsung memberikan bantuannya kepada pasangan. Pada saat itu KK mempercayai pasangan dalam menyelesaikan masalah atau kasusnya.

"..dan waktu itu dia cuman sebe.. maksudya butuh bantuan butuh bantuan dan saya ngasih aja gitu. Dan saya ngasih tanpa saya mempertanyakan gitu loh jadi.." (KK45) 
Akan tetapi, pada perkembangannya, situasi semakin tidak terkendali dan akhirnya membuat pasangan KK harus ditahan oleh kejaksaan. Perasaan KK ketika awal kasus adalah kaget. KK tidak menyangka ada kasus yang menimpa pasangan. Kemudian KK berusaha mencari solusi atas kasus tersebut. Setelah kasus berkembang, KK merasakan banyak perubahan-perubahan yang membuat keluarganya dalam keadaan tidak baikbaik saja. Namun, lama-kelamaan KK berusaha beradaptasi dengan keadaan keluarga.

"pasti.. sedih ya. Karena kan dulunya baik sekarang gak baik kayak gitu-gitu, cuman lama-lama ya... ya... lama-lama ya.. apa ya, ya berusaha memberi adaptasi aja sih." (KK164)

KK menganggap bahwa korupsi adalah sesuatu yang buruk dan merugikan. Korupsi juga menyalahi komitmen dan merupakan penipuan serta mengambil sesuatu yang bukan haknya. Persepsi KK terhadap korupsi sebagai sesuatu yang buruk menyebabkan sikapnya tidak setuju terhadap tindak pidana korupsi.

"Korupsi memang sesuatu yang buruk ya. Buruk dalam artian ya memang itu merugikan. Jadi bukan hanya buruk secara.. merugikan sih sebetulnya itu aja...yaa merugikan ya karena kan itu apa, menyalahi komitmen dan sebagainya, melakukan penipuan... mengambil sesuatu yang bukan haknya, seperti itu." (KK170)

Menurut KK persoalan korupsi adalah persoalan personal dan tanggung jawab personal. Akan tetapi, sering kali pasangan seolah-olah dianggap menjadi bagian dari perilaku korupsi. KK meminta untuk tidak menggeneralisasi kasus korupsi yang menyangkut pasangan karena hal tersebut bergantung pada konteks dan membutuhkan riset yang panjang serta pemeriksaan yang komprehensif. KK berusaha membantu dengan mencarikan teman-teman yang bisa membantu untuk menyelesaikan kasus, namun pasangan tidak mau terbuka dengannya atas kasus tersebut. Pada awal kasus, KK selalu menghindar dari pasangan. Penghindaran KK membuat pasangan juga tidak mau bercerita karena takut menghadapi sikap KK setelah mengetahui kasus pasangan. Lamakelamaan KK merasa lelah dengan semuanya

“..jadi waktu itu saya menghindar menghindar lama-lama jadi besar. Tapi saya gak tau sampai saat ini saya masih ga tau kenapa ini jadi menjadi sangat besar gitu kan masalahnya tuh gimana gitu.." (KK44)

Saat KK mendengar kabar bahwa pasangannya ditahan, KK yang sedang berada di luar negeri shock mendengar kabar tersebut. KK juga sedih dan memikirkan anaknya yang sedang ditinggal olehnya dan saat itu juga harus ditinggal oleh ayahnya. 
"Sy sedih sih tapi ya bagaimana lagi. ... Ya sedih karena hidup kok drama sekali begini.” (WA6)“Sad, that'sall.” (IG19)

Kepergian KK ke luar negeri untuk sekolah membuat KK berharap bahwa pasangannya dapat menggantikan perannya kepada anaknya. Akan tetapi, pasangan ditahan oleh Kejaksaan, KK berpikir bahwa apa yang diharapkannya tidak bisa terwujud lagi. Apa diharapkannya sudah gagal karena pasangannya tidak bisa bersama anaknya. KK merasa kecewa atas kegagalan dari rencananya tersebut.

“..Dan ketika bapaknya ngga bisa artinya kan gagal nih apa yang saya inikan, rencanakan kan gagal, jadi saya sedih, saya kecewa gitu, marah itu kan,.." (KK92)

Setelah pasangan divonis, kemarahan KK kepada pasangan muncul karena setelah proses hukum atas kasus yang dijalani pasangannya, akhirnya pasangan dipenjara. KK merasa bahwa pasangannya tidak bertanggung jawab. KK merasa bahwa dirinya telah disakiti, dibohongi, dan dibodohi oleh pasangannya.

"Having no idea what is going on your mentality is very painful. But after realizing what becomes your mentally problem, it is more painful. So don't try to cure your se funless you have unbreakable courage." (IG12)

"May be it's true to not invite others who just know how to hurt. They, attheend are not morethatliars." (IG15)

KK merasa takut terhadap orang-orang yang berdatangan ke rumahnya untuk mencari pasangan untuk menagih hutang dengan menerornya. Ketakutannya membuat KK pindah ke rumah orang tuanya bersama anaknya.

“..Jadi saya cuma tinggal sama anak saya trus akhirnya saya tidak. Pilih pulang ke rumah karena takut kan saya di rumah sendiri, berdua sama anak sama pembantu. Trus banyak orang yang nyariin dia dan sebagainya, posisinya seperti itu teruskan saya balik ke rumah ibu sayakan.." (KK49)

Perasaan lain yang sering dirasakan oleh KK adalah merasa kehilangan dan terguncang secara psikologis. Ia merasakan kehilangan banyak hal mulai dari materi, teman, relasi, maupun mimpinya. KK merasa gagal dan kehilangan dream-comes-true-nya sebagai keluarga yang penuh kebahagiaan. 
“..kesepian tiba-tiba nangis sendiri gitu sering juga..." (KK83)

KK juga sering merasa tidak bahagia terhadap hidupnya. Ia merasa bahwa pencapaianpencapaian yang dilakukannya tidak membuatnya bahagia dan sering merasa sedih. KK juga tidak bisa meyakinkan dirinya untuk bahagia atas hidupnya.

“..Saya sulit sekali merasakan bahwa saya bahagia atau saya sulit sekali merasa percaya diri bahwa saya tuh lagi bahagia ya itu sih ya banyak faktor ya saya juga karena persoalan ini gitu.." (KK136)

Saat KK sudah berada di luar negeri, pasangan sering kali sulit untuk dihubungi dan menghilang tanpa kabar. Merasa tidak sanggup lagi menahan derita, KK berpikir untuk berpisah dengan pasangan. KK merasa pasangan juga tidak mampu membuat situasi menjadi lebih baik setelah ia berada di luar negeri. KK yang biasanya aktif di media sosial, menjadi tidak pernah muncul sejak pasangannya berkasus. Bahkan, KK juga pernah bermimpi dirinya menangis sampai sesak nafas.

“..saya sering mimpi buruk, iya, saya ga bias tidur, iya, sering nightmare, iya sering mimpi yang saya lari-lari kemana atau saya marah marah gitu, sering. Terus mimpi yang nangis sampe sesak napas, sering...” (KK83)“..yang kaya saya ceritakan kemarin itu saya mimpi buruk.." (KK131)

Setelah beberapa lama ditahan dan melalui persidangan, pasangan KK akhirnya divonis dengan hukuman penjara 4 tahun 6 bulan dan denda 200 juta subsidair 3 bulan kurungan. Pada saat itu KK merasa sangat marah kepada pasangan yang akhirnya membuat KK tidak ingin bertemu maupun berhubungan dengan semua orang yang berkaitan dengan pasangannya, termasuk keluarga mertuanya selama hampir 1 tahun.

“pokoknya ketika dia vonis yang saya tau ketika dia vonis seperti saya gak mau ngomong sama siapa pun sampe 6 bulan hampir 1 tahun lah saya ga ketemu sama dia itu.." (KK65)

\section{Keputusan untuk melanjutkan sekolah di luar negeri}

Di tengah-tengah kondisi yang menekan itu, KK mendapat kabar bahwa dirinya sudah dapat sekolah (di luar negeri). Saat pertama peneliti tanya mengapa KK memutuskan untuk tetap pergi sekolah dalam kondisi keluarga yang sedang tidak stabil, KK berusaha mengingatnya. Pada saat itu KK mengalami dilema. Di satu sisi, sekolah di luar negeri 
adalah keinginannya untuk pencapaian dan sudah disiapkannya dari lama. Di sisi lain, jika KK berangkat ke luar negeri, KK meninggalkan anaknya dalam kondisi keluarga yang sedang bermasalah.

"Waktu itu saya juga ga ngerti ya saya juga ga inget kalo yang ditanyain kenapa waktu itu saya memutuskan untuk berangkat saya berusaha untuk mengingat sebetulnya kok bisa di waktu itu saya berangkat, ko bisa ya saya punya keberanian meninggalkan anak saya sendiri dalam kondisi suami saya yang seperti itu? Saya tuh mencoba sampai saat ini saya coba mengingat kenapa saya punya keputusan itu waktu itu. Apa yang sebetulnya..waktu itu saya ga bisa ingat sebetulnya. Pokoknya akhirnya, Ya saya udah berangkat saya sampai di (menyebut nama negara) itu..." (KK51)

Pada wawancara berikutnya, ketika peneliti tanya kembali alasan KK atas keputusan tetap sekolah di luar negeri. KK mengatakan bahwa keputusan untuk sekolah adalah bagian dari tanggung jawab pekerjaannya. Di tempatnya bekerja, dianjurkan untuk melanjutkan studi di luar negeri. Saat mendaftar, KK diterima di beberapa tempat dan akhirnya memilih di satu sekolah dengan alasan sekolah yang dipilihnya prosesnya lebih cepat sehingga bisa langsung berangkat sekaligus mendapatkan beasiswanya. Pilihan tersebut adalah pilihan yang berani karena dengan memilih sekolah di tempat tersebut membuat KK harus berangkat dengan segera dalam kondisi harus meninggalkan anaknya dengan pasangan yang berkasus dan perkataan-perkataan orang lain yang menyatakan bahwa dirinya sangat tega meninggalkan suami yang sedang memiliki masalah. KK sering menangis memikirkan apakah keputusannya benar atau tidak. Meskipun demikian, KK akhirnya tetap berangkat sekolah ke luar negeri. Melanjutkan pendidikan di luar negeri sudah menjadi impian KK. Lebih lanjut lagi, saat itu KK berpikir bahwa pasangannya dapat memenuhi perannya terhadap anak mereka, sehingga KK tidak terlalu merasa bersalah dengan meninggalkan anak.

"It was about two years ago, I had to come to this country with a lot oftears. I had no idea what made me to be very brave at that time. Maybe yes I had a big dream eventhough I regrettably left my baby in the very confusing case behind...." (IG21)

"iya dia sempet cerita, dia mau berangkat dalam keadaan semuanya itu dia sempet cerita. Banyak juga orang yang bilang e.... apa, tega banget gitu jadi istri, suami lagi menghadapi musibah malah pergi banyak itu yang men-judge dia ya karena pendidikan udah jadi targetnya dia ya...." (KD29) 
“...saya melakukan saya men-denied banyak hal, itu yang saya merasa berat gitu kan saya gak bisa. Kenapa saya gak bisa ketemu sama anak saya gitu kan saya kan ibunya dan sebagainya kenapa saya dapet sekolah tapi harus pisah sama anak saya...." (KK136)

Keputusan KK untuk mengambil kesempatan sekolah didukung pasangannya. Saat itu pasangan berpikir bahwa jika pertimbangannya adalah berat meninggalkan pasangan karena sedang berkasus, maka pasangan menginginkan agar KK tetap pergi. Alasannya, pasangan ingin membagi beban. Jika KK tidak jadi sekolah karena kasus pasangan, maka pasangan akan menjadi satu-satunya yang disalahkan, sedangkan jika KK tetap berangkat sekolah, beban tersebut akan menjadi tanggungan bersama.

\section{Perceraian}

Keinginan KK untuk berpisah dengan pasangan sebenarnya sempat muncul ketika KK yang pada saat itu sudah berada di luar negeri kesulitan menghubungi pasangan. KK berpikir bahwa pasangannya sudah tidak bisa diandalkan lagi dalam memegang tanggung jawab. Ditahannya pasangan adalah pemantik terkuat dari kembalinya keinginan KK untuk bercerai. Orang-orang yang berdatangan mencari-cari pasangan, dan penagih-penagih hutang yang datang bahkan sampai meneror membuat KK merasa lelah. KK sudah kehilangan semuanya dan merasa sudah tidak ada harapan lagi bersama pasangan.

\section{Motif perlindungan, perbaikan diri dengan menerima dan memaafkan}

Setelah menghadapi kasus pasangan yang berujung pada ditahannya pasangan dan perceraian yang dilakukan, KK mengevaluasi diri dan memahami diri sendiri. KK memaknai hubungan yang equal antara suami dan istri hanya sebatas teori. KK akhirnya menyadari bahwa untuk membentuk hubungan yang equal antara suami-istri dibutuhkan pemahaman terhadap pasangan. Mengenal dan memahami pasangan bukan hanya secara kognitif (e.g., pekerjaannya atau teman-temannya) namun juga memahami secara emosional mengenai karakter kepribadian suami. Setelah melalui semua proses kasus dan pengalaman konselingnya, KK menyadari bahwa semua itu harus ia terima sebagai bagian dari jalan hidupnya. Dengan mengenali, memahami, dan menerima apa yang ada pada diri dan apa yang dialami, KK belajar untuk memaafkan diri sendiri dan orang lain. KK berpikir bahwa yang menjadikan dirinya saat ini adalah hasil dari apa yang dia alami sebelumnya. KK lebih memilih untuk memaafkan masa lalu dan memulai untuk menyambut sesuatu yang lebih baik.

"Don't hate the past. Don't be angry at history. They are why we are today. Let's make our own history. If some are good, we maycelebrate it. If not, we need to learn just forgive it." (BLOG24) 
Meskipun KK membutuhkan waktu yang cukup lama, yaitu dua tahun baginya untuk bisa memahami dan menerima, namun KK merasa lebih tenang untuk bisa memaafkan diri sendiri dan orang lain. Waktu dua tahun adalah waktu yang cukup bagi KK untuk memulai semuanya kembali.

"Untuk ibumu sedikit lebih tenang dalam memaafkan diri sendiri maupun mereka." (IG14)

\section{Pemulihan dan perbaikan diri demi tumbuh kembang anak}

Menghadapi kasus yang menimpa pasangan, KK menyadari bahwa psikologisnya terganggu dan terluka. Menyadari hal tersebut, KK meminta tolong kepada temannya yang sarjana psikologi. Teman KK merekomendasikan untuk mengikuti program konseling yang ada di tempat kuliahnya di luar negeri. KK menjalani konseling selama enam bulan. Menurut KK, dari konseling itu ia jadi mengerti banyak hal, termasuk mengenai dirinya sendiri.

“....jadi saya itu konsultasi dengan beberapa psikolog sebetulnyakan. Jadi saya ngga mau ngomong gitukan sebetulnya saya eee konseling disana. Jadi saya kan difasilitasi sama kampuskan untuk konseling itu gratis kan kalau disana dan konseling di sana tuh ngga yang..konseling di sana tuh ngga yang dateng terus Tanya gitu engga, tapi beneran seminggu sekali dateng dan apa yang kita mau omongin tuh terserah apa yang kita mau omongin gitu loh. Jadi bukan kayak langsung disembuhkan gitu, tapi beneran observasinya tuh dari awal gitu. Jadi saya selama 6 bulan itu saya proses konseling. Mungkin itu ya yang faktor yang kemudian saya mau, ya okey saya mau mencoba memaafkan, saya mencoba ngobrol lagi, saya mau coba untuk yaa menghadapi gitukan.." (KK72)

Setelah KK melakukan konseling, pasangan juga merasakan perubahan-perubahan perilaku yang lebih baik dalam arti perilaku mendekat (approach behavior) dari KK kepada pasangan. Pemahaman KK mengenai dirinya dan evaluasi diri membuat KK mampu memikirkan perilaku yang seharusnya ia lakukan dalam kondisi-kondisi tertentu, misalnya KK jadi lebih mempertimbangkan dan berdiskusi dengan orang lain ketika anaknya ingin bertemu dengan pasangan yang sedang berada di lapas. KK tidak mengambil keputusan sendiri dengan hanya mengedepankan hal-hal pragmatis, tapi lebih banyak pertimbangan baik-buruknya terhadap psikologis anak. Setelah semua yang dialami oleh KK, dari berjuang menghadapi kasus sampai mengalami perceraian, KK memikirkan anaknya. KK mengkhawatirkan psikologis anaknya akan terganggu akibat dari kasus pasangan dan perceraiannya tersebut. Terlebih, anaknya hanya mengetahui bahwa ayahnya sedang bekerja di luar kota, padahal ayahnya berada di lapas dan tidak pernah bertemu selama 2 tahun. Dengan status pasangan yang sekarang sebagai warga 
binaan pemasyarakatan (WBP), KK tidak ingin anaknya memiliki pandangan negatif terhadap diri ayahnya. KK tidak ingin anaknya merasa malu memiliki seorang ayah mantan narapidana. Karena hal tersebut, KK ingin anaknya memiliki kebanggaan atas orang tuanya, dengan cara mengembalikan pandangan diri yang positif akan pasangan sebagai ayah dari anaknya.

“...saya kalo saya gimana ya karena dia kan bapaknya anak saya ya saya tuh selalu berjuang kalo gimana anak saya tuh selalu dapet pride dari orang tuanya gitu aja sih fokus saya ya dan saya pikir dia mau bekerja sama dengan itu demi kepentingan.. saya sebetulnya kan demi kepentingan anak saya ya jadi tetep punya kebanggaan orang tuanya tetep punya ingatan baik tentang orang tuanya itu yang selalu saya upayakan ya gimana caranya dia punya ingatan baik tentang kita gitu apapun, apapun kondisinya gitu..." (KK151)

KK akhirnya berpikir bahwa paling tidak ia masih memiliki anak yang bisa membuatnya tetap merasa hidup.

"At least I still have reason why I should be alive. Mother will never die." (IG22)

Keinginan KK terhadap pandangan baik anak akan orang tuanya dikomunikasikan kepada pasangan. KK merasa bahwa pasangan mau untuk diajak bekerja sama demi kepentingan anak. KK melihat bahwa pasangan berusaha untuk tetap memiliki manfaat melalui menulis maka KK terus mendukung pasangan untuk mewujudkannya. Hal tersebut adalah cara KK untuk membangun kebanggaan anaknya terhadap orang tuanya.

“...Saya gak tau kalo itu tapi yang saya lihat eee... dia sekarang sedang berusaha untuk tetap mempunyai manfaat begitu. Dengan menulis, dan sebagainya dan eee... kalo yang saya selalu bilang ke dia adalah saya tuh pengennya anak saya punya kebanggaan dengan kita ya saya pikir dia mau bekerja sama dengan itu..." (KK151)

\section{Diskusi}

Tujuan dari penelitian ini adalah melihat gambaran dinamika psikologis rasa malu seorang istri yang bercerai ketika suami divonis tindak pidana korupsi. Partisipan merasa malu atas perbuatan yang dilakukan pasangan. Emosi malu memiliki konstruk yang cukup rumit. Oleh karena itu, peneliti berusaha mengindentifikasi emosi malu yang dialami oleh partisipan melalui marah, sakit, merasa kurang (defect), takut (karena terekspos/terpapar), kesepian, kehilangan, tidak bahagia, dan tidak berdaya. 
Peneliti menilai bahwa kemarahan partisipan yang keluar terhadap pasangan merupakan bentuk dari pertahanan diri. Pertahanan diri dilakukan dalam rangka menanggapi kritik atau evaluasi publik yang melukai citra diri sosialnya. Sesuai dengan pernyataan Lewis (Hejdenberb \& Andrews, 2011) bahwa kemarahan pada orang lain (pasangan) ini memungkinkan individu yang malu untuk mendapatkan rasa kendali dan kelegaan dari pengalaman malu yang menyakitkan.VandenBos (2007) menjelaskan bahwa perasaan adalah penilaian subjektif intrafisik individu sedangkan emosi adalah pola reaksi yang diekspresikan seseorang ketika tergugah dengan peristiwa atau kejadian signifikan yang dialaminya. Emosi malu tersebut diekspresikan karena istri merasa menerima penolakan dari lingkungan akibat kasus korupsi suami sebagai bagian dari peristiwa traumatis dalam hidup pasangan ini. Istri marah, sedih, dan kecewa dapat diidentifikasikan sebagai dinamika intrafisik (intrapersonal) subjektif yang dirasakannya secara subjektif. Perasaan marah yang dirasakan partisipan timbul dari adanya rasa malu yang lebih dahulu dirasakan oleh partisipan. Hal ini sesuai dengan penelitian Gilbert, et al. (Malinen, 2010) bahwa rasa malu berhubungan erat dengan kemarahan terhadap orang lain.

Ketika istri mengetahui keterlibatan suami dalam kasus korupsi, maka ia mengekspresikannya dengan menghindari dan menolak kenyataan. Reaksi ini merupakan koping dari rasa malu yang dialaminya. Perilaku partisipan yang tidak mau tahu lagi mengenai kasus pasangan menunjukkan bahwa partisipan ingin memikirkan hal yang lain dan tidak ingin mengingat pengalaman yang memicu rasa malu tersebut. Menurut Lewis (Malinen, 2010), meskipun seseorang berhenti berfokus dan menyangkal rasa malu, rasa malu tersebut masih tetap eksis. Pada saat yang bersamaan, partisipan mendapatkan beasiswa untuk sekolah di luar negeri. Hal ini menjadi pengalihan fokus dan target untuk forgetting yang tepat bagi partisipan atas rasa malunya. Pasalnya, ditahannya pasangan bukanlah perkara yang mudah. Sejak awal, partisipan berusaha membantu pasangan agar kasusnya tidak sampai masuk persidangan. De Hooge et al. (2011) menyebut hal ini sebagai faktor situasional yang memungkinkan untuk memunculkan motif perlindungan dalam situasi membahayakan. Rasa malu yang didukung dengan adanya penolakan memunculkan perilaku menghindar (Gausel et al., 2012).

Partisipan berpikir secara rasional bahwa kasus korupsi pasangan dan membuat citra dirinya terancam, sehingga salah satu cara yang dapat memulihkannya adalah dengan meraih penghargaan atau pencapaian (Tracy et al., 2007). Meraih pencapaian dilakukan oleh partisipan dengan cara mengambil kesempatan sekolah ke luar negeri. Maka, pada saat itu fokus partisipan adalah meningkatkan kebanggaan diri sebagai cara untuk keluar dari rasa malu. Langkah berani ini didukung dengan profil kepribadian sang istri yang aktif, dominan, dan aktivitasnya sebagai seorang aktivis.

Menurut teori Vicariousshame, individu dapat merasakan malu atas tindakan negatif orang lain karena adanya perasaan empati dan identitas bersama. Namun, dalam kasus 
ini rasa malu yang dialami oleh partisipan didominasi oleh adanya identitas bersama dibandingkan dengan rasa empati terhadap pasangan. Lickel, et al. (2005) menyebut identitas bersama sebagai prediktor dari rasa malu yang dialami oleh pasangan. Ketika pelaku pelanggaran merupakan orang yang familier dengan individu, maka faktor identitas sosial adalah yang menyebabkan munculnya rasa malu (Welten et al., 2012). Partisipan mengaku membantu pasangan baik secara finansial maupun non finansial. Perilaku ini lebih cenderung didasari oleh keinginan partisipan agar masalah cepat selesai dan tidak ingin terus terlibat dalam masalah dan konflik dengan pasangan.

Dengan memersepsikan adanya keterhubungan dengan pasangan, partisipan juga merasa bahwa ada penilaian negatif telah mengancam citra diri pribadi akibat dampak kasus korupsi pasangannya. Hal ini berdampak pada relasi sosial partisipan seperti reputasi sosial dan relasi dengan teman-teman satu pekerjaannya. Keputusan partisipan untuk bercerai didukung oleh keluarga besar dan teman dekat partisipan. Welten et al. (2012) mengemukakan bahwa pada rasa malu berbasis identitas, rasa malu berfungsi untuk menghukum orang yang membuatnya malu. Pada penelitian ini, partisipan bukan menghukum, melainkan memutus identitas bersama dengan partisipan melalui perceraian.

Secara ekonomi dan status sosial, keluarga partisipan adalah keturunan keluarga yang berkecukupan, dengan menganut nilai-nilai normatif dan religius (parental belief and practices) (Tangney \& Dearing, 2002). Secara religi maupun norma, korupsi merupakan hal yang buruk dan merupakan pelanggaran. Maka, persepsi tersebut membentuk standar dalam keluarga bahwa korupsi merupakan hal yang bertentangan dengan agama dan norma sosial. Oleh karenanya, kemungkinan rasa malu timbul dari perilaku yang melanggar norma. Lebih lanjut lagi, keluarga besar partisipan juga harus menanggung hutang-hutang pasangan yang akhirnya menguras aset keluarga. Maka, perceraian adalah jalan keluar bagi partisipan untuk menyelamatkan diri dari rasa malu sebagai istri koruptor.

Setelah bercerai dan pasangan divonis 4 tahun 6 bulan kurungan di lapas, partisipan memutus seluruh komunikasi antara dirinya dengan pasangan maupun orang-orang yang berhubungan dengan pasangan. Akan tetapi, partisipan memikirkan hubungan antara anaknya dan pasangan. Partisipan tidak ingin anaknya merasakan malu memiliki ayah seorang koruptor dan narapidana. Oleh karena itu, partisipan berpikir untuk mengembalikan citra diri yang positif pasangan sebagai ayah bagi anaknya dengan memperbaiki hubungannya.

Dinamika rasa malu yang dialami oleh partisipan tidak sama dengan yang dijelaskan oleh dihomogen et al. (2011) yang menyebutkan bahwa rasa malu yang dialami individu menghasilkan kecenderungan untuk mengaktifkan motif perbaikan terlebih dahulu. Berbeda dengan pernyataan tersebut, rasa malu yang dialami partisipan penelitian ini justru mengaktifkan kedua motif perbaikan dan perlindungan secara bersamaan. Secara konteks, penelitian yang dilakukan de Hooge et al., (2011) dilakukan pada partisipan yang 
merasakan malu atas perbuatannya, sedangkan pada penelitian ini, partisipan merasakan malu atas perbuatan pasangannya.

Lebih lanjut lagi, dinamika psikologis rasa malu pada partisipan penelitian ini dipengaruhi oleh beberapa hal. Peneliti berusaha menggarisbawahi mengenai konteks karakteristik partisipan dan relasi dengan pasangan. Relasi antara partisipan dan pasangan cenderung memiliki kohesivitas rendah. Kecenderungan partisipan untuk menghindari masalah-masalah yang datang di dalam keluarga dan pencarian power luar lingkup keluarga, menjadikan keluarga bukanlah sebagai tempat untuk bersandar dan saling bahu-membahu satu sama lain di tengah masalah. Selain itu, dengan keinginan partisipan dalam mengejar penghargaan dan terus menaikkan harga dirinya membuat pasangan smakin tertinggal jauh dari partisipan. Hal ini membuat relasi dengan pasangan semakin tidak berfungsi dengan baik. Masing-masing sibuk menaikkan kebanggaan diri tanpa amelibatkan dan menyadari bahwa masing-masing merupakan bagian dari keluarga. Olson et al. (2014) menyarankan untuk membangun intimasi dan kepuasan perkawinan setidaknya diperlukan lima kunci utama yakni komunikasi, kedekatan, fleksibilitas, kesesuaian kepribadian, dan resolusi konflik.

Berdasarkan relasi dengan pasangan, interaksi antara partisipan dan pasangannya sudah mulai memburuk ketika awal munculnya kasus. Kohesivitas keduanya melemah karena komunikasi yang tidak transparan dalam hal pekerjaan dan atau penghasilan pasangan. Selain itu, komunikasi juga cenderung tidak intensif, sehingga, ketika masalah muncul, masing-masing (partisipan dan pasangan) tidak ingin melebur, melainkan melepaskan diri. Dalam hubungan dengan suprasistem, kedekatan partisipan dengan ibu dan bantuan-bantuan yang diberikan kepada partisipan memiliki pengaruh yang cukup besar. Saat pasangan tidak dapat hadir dalam menggantikan peran ayah untuk mengurus anak ketika KK berada di luar negeri, KK membutuhkan bantuan ibunya untuk mengurus anaknya.

Penelitian ini menghasilkan temuan penelitian berupa dinamika psikologis rasa malu pasangan (istri) koruptor yang dapat dilihat pada Gambar 2. 


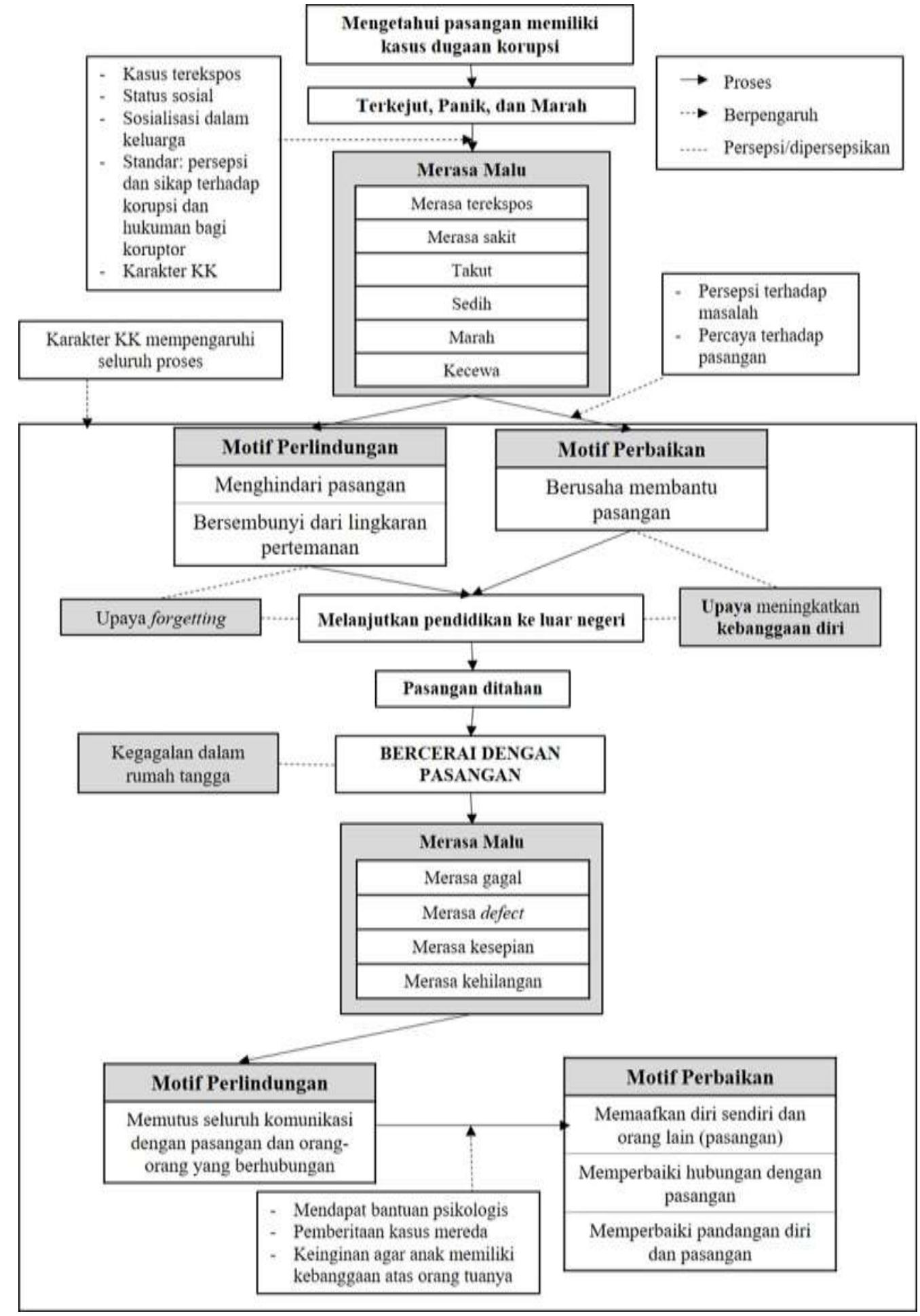

Gambar 2. Dinamika rasa malu pasangan (istri) koruptor

Implikasi rasa malu dengan peran keluarga terhadap perilaku korupsi 
Hasil penelitian menunjukkan bahwa rasa malu selain memunculkan perilaku menghindar, tetapi juga memiliki fungsi positif dengan memunculkan usaha-usaha perbaikan diri. Penolakan dari keluarga partisipan terhadap pasangan mendorong partisipan untuk bercerai dengan pasangan. Dari hasil tersebut, dapat disimpulkan bahwa dampak terburuk dari perilaku korupsi terhadap keluarga adalah perceraian.

Rasa malu juga memotivasi partisipan untuk melakukan perbaikan-perbaikan tentang citra diri. Merupakan hal yang sangat baik jika usaha-usaha perbaikan ini dilakukan dengan cara yang tepat sesuai dengan norma yang ada di masyarakat. Perbaikan pandangan dengan meningkatkan pencapaian melalui pendidikan dan menulis merupakan manifestasi yang positif dari rasa malu. Rasa malu juga memiliki peran memfasilitasi pembelajaran yang akan membantu individu membuat respons yang sesuai di masa depan (Feldman, 2012). Pembelajaran tersebut terjadi pada partisipan. Ketika ditanya mengenai nilai-nilai apa yang ingin ditanamkan kepada anak, partisipan menjawab kejujuran. Kejujuran berimplikasi dengan integritas seseorang di mana integritas adalah karakter yang positif bagi individu.

\section{Kesimpulan}

Hasil penelitian menunjukkan bahwa seorang istri dapat merasakan malu akibat dari tindak pidana korupsi yang dilakukan oleh suaminya. Rasa malu tersebut termanifestasi dalam perasaan sedih, sakit, marah, kecewa, kehilangan, kesepian, defect, perasaan tidak bahagia, dan perasaan takut. Rasa malu yang dirasakan oleh partisipan karena adanya identitas bersama antara partisipan dengan pasangan. Koping yang dilakukan untuk mengusir rasa malunya adalah dengan menghindari pasangan dan melakukan forgetting dengan membantu pasangan menyelesaikan kasusnya. Mempertimbangkan kondisi psikologis anak menjadi faktor yang memperbaiki hubungan dengan pasangan dan mengembalikan pandangan yang positif terhadap diri.

Faktor personal dan faktor situasional berpengaruh terhadap dinamika rasa malu yang dialami partisipan. Faktor personal yang berpengaruh adalah karakteristik partisipan dan keinginan partisipan agar anaknya tidak kehilangan kebanggaan atas orang tuanya. Faktor situasional yang berpengaruh adalah ditahannya pasangan, kejadian-kejadian setelah penahanan pasangan, isu-isu dibalik kasus, mendapatkan bantuan psikologis, peran teman dekat, dan relasi dengan pasangan.

\section{Saran}

Hasil penelitian menunjukkan bahwa perilaku korupsi yang dilakukan oleh pasangan dapat membuat pasangan lainnya merasakan malu. Hal ini memungkinkan pencegahan korupsi melalui keluarga. Selain itu, rasa malu yang timbul akibat perilaku korupsi yang sudah dilakukan juga dapat dijadikan sebagai motivasi untuk memperbaiki pandangan 
diri yang positif, sehingga ke depannya, baik keluarga maupun pelaku dapat diterima kembali di masyarakat. Penelitian selanjutnya diharapkan mampu untuk meneliti rasa malu keluarga koruptor dengan kelompok partisipan dari variasi demografis dan relasi keluarga yang beragam.

\section{Kepustakaan}

Altalib, H., AbuSulayman, A., \& Altalib, O. (2013). Parent-child relations: A guide to raising childrenn. The International Institute of Islamic Thought.

Antarafoto.com. (2017, Desember 25). Menjenguk suami di rutan KPK. Dipetik 1 8, 2018, dari Antara Foto: https://www.antarafoto.com/peristiwa/v1514194801/menjenguksuami-di-rutan-kpk

De Hooge, I. E., Zeelenberg, M., \& Breugelmans, S. M. (2010). Restore and protect motivations following shame. Cognitioan and Emotion, 24(1), 111-127. https://doi.org/10.1080/02699930802584466

De Hooge, I. E., Zeelenberg, M., \& Breugelmans, S. M. (2011). A functionalist account of shame-induced behaviour. Cognition and Emotion, 25(5), 939-946. https://doi.org/10.1080/02699931.2010.516909

Feldman, R. S. (2012). Pengantar psikologi: Understanding psychology (Ed. 10, Vol. 2). (P. G. Gayatri, \& P. N. Sofyan, Penerj.) Salemba Humanika.

Gausel, N., Leach, C. W., Vignoles, V. L., \& Brown, R. (2012). Defend or repair? Explaining responses to in-group moral failure by disentangling feelings of shame, rejection, and inferiority. Journal of Personality and Social Psychology, 102(5), 941-960. https://psycnet.apa.org/record/2012-04356-001

Gerring, J. (2007). Case study research: Principles and practice. Cambridge University Press

Goffman, E. (1955). On face-work: An analysis of ritual elements in social interaction. Psychiatry: Interpersonal and Biological Processes, 18(3), 213-231. https://doi.org/10.1080/00332747.1955.11023008

Goldenberg, H., \& Goldenberg, I. (2013). Family therapy: An overview. Brooks/Cole Cengage Learning.

Hejdenberg, J., \& Andrews, B. (2011). The relationship between shame and different types of anger: A theory-based investigation. Personality and Individual Differences, 50, 1278-1282. https://doi.org/10.1016/j.paid.2011.02.024

Kahija, L. Y. (2017). Penelitian fenomenologis: Jalan memahami pengalaman hidup. PT. Kanisius.

Lickel, B., Schmader, T., Curtis, M., Scarnier, M., \& Ames, D. R. (2005). Vicarious shame and guilt. Group Process and Intergroup Relations, 8(2), 145-157. https://doi.org/10.1177/1368430205051064

Mahfud, M. (2016, November 12). Melihat derita koruptor. Diambil kembali dari SindoNews.com: https://nasional.sindonews.com/read/1154769/18/melihat-deritakoruptor-1478917339/13 
Malinen, B. (2010). The nature, origins, and consequences of finnish shame-proneness: A grounded theory study. Finland: Faculty of Theology University of Helsinky. Dipetik Juli 24, 2018, dari https://helda.helsinki.fi/bitstream/handle/10138/21627/thenatur.pdf?sequence=1

Merdeka.com. (2013, Mei 16). Sefti jenguk suami di KPK. Dipetik Januari 8, 2018, dari Merdeka.com: $\quad$ https://www.merdeka.com/foto/peristiwa/191275/20130516121335sefti-jenguk-suami-fathanah-di-kpk-001-d-n.html

Olson, D. H., DeFrain, J., \& Skogrand, L. (2011). Marriages and families: intimacy, diversity and strengths (Edisi ketujuh). McGraw Hill.

Olson, D. H., DeFrain, J., \& Skogrand, L. (2014). Marriages \& families: Intimacy, diversity, and strengths (Edisi kedelapan). McGraw-Hill Education.

RMOL.CO. (2014, Mei 28). Ratu Rita kembali jenguk Akil Mochtar. Dipetik dari RMOL.CO: Kantor Berita Politik: http://www.rmol.co/read/2014/05/28/157066/RatuRita-Kembali-Jenguk-Akil-Mochtar-

Tangney, J. P., \& Dearing, R. L. (2002). Shame and guilt. The Guilford Press.

Tangney, J. P., Stuewig, J., \& Martinez, A. G. (2014). Two faces of shame: The roles of shame and guilt in predicting recidivism. Psychological Science, 25(3), 799-805. https://journals.sagepub.com/doi/full/10.1177/0956797613508790

Tangney, J. P., Stuewig, J., \& Mashek, D. J. (2007). Moral emotion and moral behavior. $\begin{array}{llll}\text { Annual Review } & \text { Psychology, } & \text { 345-372. }\end{array}$ https://dx.doi.org/10.1146/annurev.psych.56.091103.070145

Tracy, J. L., Robins, R. W., \& Tangney, J. P. (2007). The self-conscious emotions: Theory and research. The Guilford Press.

Transparency International Indonesia. (2010, November 9). Indeks persepsi korupsi Indonesia 2010. Dikutip Maret 25, 2017, dari Transparency International Indonesia: https://www.ti.or.id/media/documents/2010/11/11/f/i/file.pdf

Tribunnews.com. (2014, Desember 10). Peran besar keluarga dalam mendorong-dorong tindak pidana korupsi. Dipetik 5 28, 2018, dari Tribunnews.com: http://www.tribunnews.com/nasional/2014/12/10/peran-besar-keluarga-dalammendorong-dorong-tindak-korupsi

VandenBos, G. R. (2007). APA dictionary of psychology. American Psychological Association.

Welten, S. C., Zeelenberg, M., \& Breugelmans, S. M. (2012). Vicarious shame. Cognition and Emotion, 26(5), 836-846. https://doi.org/10.1080/02699931.2011.625400

Zane, N., \& Yeh, M. (2002). The use of culturally-based variables in assessment: Studies on loss of face. Dalam K. S. Kurasaki, S. Okazaki, \& S. Sue, Asian American mental health: Assessment methods and theories (hal. 123-138). Netherlands: Kluwer Academic Publishers. 